\title{
Social class and risk factors for coronary heart disease in the Federal Republic of Germany. Results of the baseline survey of the German Cardiovascular Prevention Study (GCP)
}

\author{
U HELMERT, ${ }^{1}$ B HERMAN, ${ }^{1}$ K-H JOECKEL, ${ }^{1}$ E GREISER, ${ }^{1}$ AND J MADANS ${ }^{2}$ \\ From ${ }^{\prime}$ the Department of Epidemiology, Bremen Institute for Prevention Research and Social Medicine, Bremen \\ FRG; and ${ }^{2}$ the Department of Health and Human Services, National Center for Health Statistics, Hyattsville, MD, \\ 20782, USA
}

\begin{abstract}
The relationship between social class and seven important risk factors for coronary heart disease has been evaluated utilising data from the German Cardiovascular Prevention Study baseline survey. Of German residents aged 25 to 69 years, 16430 were randomly selected from both the six intervention regions and the Federal Republic of Germany to undergo the screening procedures between 1984 and 1986. Among males the prevalence of cigarette smoking and lack of physical activity was associated with social class. For females, overweight and physical activity demonstrated a strong social gradient. No relationship existed between social class and hypercholesterolaemia. The prevalence of Type A behaviour was significantly higher for the upper social classes. The number of CHD risk factors per study subject increased with decreasing social class. Predicted cardiovascular mortality was clearly higher for the lower social class among males in general and for females younger than 60 years. These findings point to the need for risk factor intervention strategies focusing more on the lower social classes in order to achieve more adequate prevention of coronary heart disease.
\end{abstract}

Primary prevention is the most important means of controlling cardiovascular disease, at present the leading cause of death in industrialised nations. ${ }^{1}$ By means of a large number of epidemiological studies, important specific risk factors for coronary heart disease (CHD) have been identified: hypercholesterolaemia (especially the fraction of cholesterol in low density lipoprotein [LDL] as opposed to high density lipoprotein [HDL] which is anti-atherogenic in its action), hypertension, cigarette smoking, obesity, lack of physical activity and coronary prone behaviour (Type A). ${ }^{2}$ These factors apparently do not account for all the coronary heart disease occurrence.

In recent years more and more evidence has accumulated regarding the important role of social class in determining health related behaviour, morbidity and mortality. ${ }^{3-8}$ Within the framework of a large scale intervention programme for the primary prevention of cardiovascular disease in the Federal Republic of Germany (begun in 1984), the German Cardiovascular Prevention Study (GCP), it was decided to consider the influence of socio-economic status on CHD risk factor prevalence, cardiovascular morbidity and mortality, and possible changes regarding the latter three variables during the study period.

It is intended that we use this information to help avoid possible incremental effects of the application of large scale intervention methods on social class differences in risk factor prevalence and CHD mortality. In Great Britain it has been shown that, although CHD mortality is declining in recent years, a considerable increase in social inequalities regarding CHD risk factors and CHD mortality has occurred. 910

\section{Methods}

The German Cardiovascular Prevention Study is a multicentre community based intervention study concerning the primary prevention of coronary heart disease (CHD) and stroke. Its main aim is to reduce the age specific mortality of these diseases (ICD-9: $410-414,430-438$ ) among persons 25-69 years of age in communities exposed to 8 years of intervention by 
at least eight per cent beyond that which one might expect based upon the mortality experience of the remaining non-intervention population (of comparable ages) of the Federal Republic of Germany. ${ }^{11}$

The intervention population encompasses six study regions comprising a total of 1228400 inhabitants. Three are metropolitan areas (Bremen North West, Stuttgart West/Vaihingen, Berlin-Spandau), one is a major city (Karlsruhe), two are smaller towns (Mosbach, Bruchsal) and one covers a rural area (Traunstein).

For the evaluation of the study, baseline health surveys have been conducted in these regions from 1984-1986. Additional surveys will be carried out in the middle (1988) and at the end (1992) of the study period. Random samples of 2700 German residents, 25-69 years of age, have been drawn in each of the six intervention regions. In addition, 8000 reference subjects have been randomly chosen from 200 sample points within the Federal Republic for the National Health Examination Survey. Identical survey procedures to those for intervention regions have been utilised. Participants in the study comprise 11594 persons in the intervention regions and 4836 persons in the reference area. Thus a response rate of $74.8 \%$ for the former and $66.7 \%$ for the latter was achieved, when regarding net samples, arrived at after deducting persons who had moved prior to the start of the survey, could not be located due to an incorrect address, or were deceased.

The examination portion of the survey comprised the measurement of height, weight, blood pressure (taken twice using the random zero sphygmomanometer) and pulse rate. The determinations of total serum cholesterol, HDLcholesterol and thiocyanate were also carried out.

Serum total cholesterol was determined by the CHOD-PAP method, and HDL-cholesterol by Boehringer Mannheim assay kit $\left(\mathrm{Mg}^{2+} /\right.$ phosphotungstic acid).

An extensive, mostly self administered, questionnaire covering, among other items, sociodemographic factors, smoking status, physical activity and Type $\mathrm{A}$ behaviour (Bortner scale $^{13}$ ), was administered to all participants.

Social class was based on an additive index of three variables: household net income, educational level of study subject, and occupational status of person in the household with the highest wage. ${ }^{12}$ For the majority of married women, the occupational level of the husband was taken into consideration. Five social class categories (I = upper class, II = upper middle class, III = middle class, IV = lower middle class, $\mathrm{V}=$ lower class) were used, as is the case in most other studies. Each contained approximately $20 \%$ of the participants.
The following definitions for CHD risk factors were used.

Hypertension was defined as systolic blood pressure $\geqslant 160 \mathrm{~mm} \mathrm{Hgand} /$ or diastolic blood pressure $\geqslant 95 \mathrm{~mm}$ $\mathrm{Hg}$ or under antihypertensive medication with normal values. The second blood pressure measurement was used for this purpose.

Hypercholesterolaemia was a total serum cholesterol of $6.50 \mathrm{mmol} / \mathrm{litre}$ or more.

$H D L$-cholesterol values of $<0.90 \mathrm{mmol} /$ litre or $<1.16 \mathrm{mmol} /$ litre were regarded as risk factors for males and females respectively.

Overweight was defined as body mass index [weight in $\left.\mathrm{kg} /(\text { height in } \mathrm{m})^{2}\right] \geqslant 30$.

Cigarette smoking was defined as smoking regularly at least one cigarette per day.

Physical inactivity. All participants who did not exercise at all or were active for $<1$ hour per week were considered physically inactive. Persons with scores $\geqslant 57$ on the Bortner-scale (14 items with value ranges from 1 to 6) were viewed as demonstrating Type A behaviour.

All statistical analyses have been done separately for each sex. In order to control for potential confounding factors such as age and regional influence, multiple logistic regression was used. ${ }^{1415}$ The prevalence odds ratio has been used as measure of the relationship between social class and the various CHD risk factors studied. Multiple logistic regression analyses were the basis for such calculations, with adjustments being applied for age and intervention region. The five social classes were included as dummy variables in the model. The reference categories for odds ratio determinations were the upper class for social class estimates and the National Health Survey (sample of the total Federal Republic of Germany) for regional ones. The data analysis was carried out with the SAS procedure "Proc-Logist". ${ }^{16}$

\section{Results}

The table shows the odds ratios for the seven risk factors investigated according to social status and after adjusting for variation in age and study region. The three risk factors which were most related to behaviour, namely cigarette smoking, overweight and physical inactivity, showed a clear social gradient. For both sexes, lack of physical activity (with an odds ratio of $5.00, p<0.001$, for lower class males and 4.48 , $p<0.001$, for lower class females) appeared to represent the risk factor with the strongest relationship to social status. Particularly for males, the lower the social class the more prevalent was cigarette smoking. The inverse association between social status and obesity was more clear-cut for females.

For hypertension, hypercholesterolaemia and low HDL-cholesterol, differences by social class were 
Table Odds ratios and crude prevalence for CHD risk factors by social class, GCP-Health Survey 1984-1986

\begin{tabular}{|c|c|c|c|c|c|c|c|c|c|c|c|c|c|}
\hline \multirow{3}{*}{$\begin{array}{l}\text { Risk factor } \\
\text { Cigarette smoking }\end{array}$} & \multirow{3}{*}{$\begin{array}{l}\text { Sex } \\
\text { M } \\
\text { F }\end{array}$} & \multirow{3}{*}{$\begin{array}{l}N \\
7818 \\
8384\end{array}$} & \multirow{3}{*}{$\begin{array}{l}\begin{array}{l}\text { Crude } \\
\text { Prevalence } \\
(\%)\end{array} \\
42 \cdot 7 \\
26 \cdot 3\end{array}$} & \multicolumn{10}{|c|}{ Odds ratios $†$} \\
\hline & & & & \multicolumn{2}{|c|}{ Upper class } & \multicolumn{2}{|c|}{$\begin{array}{l}\text { Upper } \\
\text { middle class }\end{array}$} & \multicolumn{2}{|l|}{$\begin{array}{l}\text { Middle } \\
\text { class }\end{array}$} & \multicolumn{2}{|c|}{$\begin{array}{l}\text { Lower } \\
\text { middle class }\end{array}$} & \multicolumn{2}{|c|}{ Lower class } \\
\hline & & & & $\begin{array}{l}1.00 \ddagger \\
(33 \cdot 2) \S \\
1.00 \\
(24 \cdot 4)\end{array}$ & $\begin{array}{l}537^{\top} \\
309\end{array}$ & $\begin{array}{l}1 \cdot 40^{* * *} \\
(41 \cdot 0) \\
1 \cdot 12 \\
(25 \cdot 8)\end{array}$ & $\begin{array}{l}682 \\
464\end{array}$ & $\begin{array}{l}1 \cdot 59 * * * \\
(42 \cdot 7) \\
1 \cdot 38 * * * \\
(28 \cdot 0)\end{array}$ & $\begin{array}{l}786 \\
584\end{array}$ & $\begin{array}{l}1 \cdot 79 * * * \\
(44 \cdot 6) \\
1 \cdot 39 * * * \\
(25 \cdot 1)\end{array}$ & $\begin{array}{l}697 \\
405\end{array}$ & $\begin{array}{l}3 \cdot 00^{* * *} \\
(56 \cdot 3) \\
1 \cdot 88^{* * *} \\
(27.6)\end{array}$ & $\begin{array}{l}647 \\
448\end{array}$ \\
\hline Hypertension & $\begin{array}{l}\mathbf{M} \\
\mathbf{F}\end{array}$ & $\begin{array}{l}7799 \\
8372\end{array}$ & $\begin{array}{l}25 \cdot 2 \\
20 \cdot 5\end{array}$ & $\begin{array}{l}1 \cdot 00 \\
(24 \cdot 7) \\
1 \cdot 00 \\
(12 \cdot 5)\end{array}$ & $\begin{array}{l}399 \\
158\end{array}$ & $\begin{array}{l}0.97 \\
(23 \cdot 8) \\
1.22 \\
(15 \cdot 7)\end{array}$ & $\begin{array}{l}393 \\
281\end{array}$ & $\begin{array}{l}1.00 \\
(25.5) \\
1.39 * * \\
(18.9)\end{array}$ & $\begin{array}{l}468 \\
394\end{array}$ & $\begin{array}{l}0.79 \\
(26 \cdot 4) \\
1.68 * * * \\
(25 \cdot 5)\end{array}$ & $\begin{array}{l}412 \\
413\end{array}$ & $\begin{array}{l}0.90 \\
(26 \cdot 0) \\
1 \cdot 69 * * * \\
(29 \cdot 2)\end{array}$ & $\begin{array}{l}296 \\
473\end{array}$ \\
\hline Hypercholesterolaemia & $\begin{array}{l}\mathbf{M} \\
\mathbf{F}\end{array}$ & $\begin{array}{l}7637 \\
8089\end{array}$ & $\begin{array}{l}33 \cdot 0 \\
34 \cdot 0\end{array}$ & $\begin{array}{l}1.00 \\
(32.0) \\
1.00 \\
(25 \cdot 9)\end{array}$ & $\begin{array}{l}507 \\
317\end{array}$ & $\begin{array}{l}1 \cdot 00 \\
(31 \cdot 6) \\
1 \cdot 27 \\
(31 \cdot 3)\end{array}$ & $\begin{array}{l}515 \\
543\end{array}$ & $\begin{array}{l}1 \cdot 06 \\
(33 \cdot 7) \\
1 \cdot 23 \\
(33 \cdot 2)\end{array}$ & $\begin{array}{l}606 \\
667\end{array}$ & $\begin{array}{l}1.04 \\
(34 \cdot 1) \\
1 \cdot 18 \\
(37 \cdot 5)\end{array}$ & $\begin{array}{l}521 \\
590\end{array}$ & $\begin{array}{l}1.01 \\
(33.9) \\
1 \cdot 13 \\
(41 \cdot 1)\end{array}$ & $\begin{array}{l}373 \\
640\end{array}$ \\
\hline Low HDL-cholesterol & $\begin{array}{l}\text { M } \\
\text { F }\end{array}$ & $\begin{array}{l}6999 \\
7487\end{array}$ & $\begin{array}{l}11 \cdot 4 \\
12 \cdot 2\end{array}$ & $\begin{array}{l}1.00 \\
(10.4) \\
1.00 \\
(7.4)\end{array}$ & $\begin{array}{r}150 \\
83\end{array}$ & $\begin{array}{l}1.05 \\
(10 \cdot 8) \\
1.31 \\
(9 \cdot 7)\end{array}$ & $\begin{array}{l}160 \\
155\end{array}$ & $\begin{array}{l}1 \cdot 16 \\
(11 \cdot 8) \\
1.67 * * * \\
(12 \cdot 4)\end{array}$ & $\begin{array}{l}193 \\
229\end{array}$ & $\begin{array}{l}1.08 \\
(11 \cdot 0) \\
1.85^{* * *} \\
(14 \cdot 3)\end{array}$ & $\begin{array}{l}156 \\
209\end{array}$ & $\begin{array}{l}1 \cdot 32^{*} \\
(13 \cdot 1) \\
2 \cdot 13^{* * *} \\
(16 \cdot 9)\end{array}$ & $\begin{array}{l}134 \\
244\end{array}$ \\
\hline Overweight & $\begin{array}{l}\mathbf{M} \\
\mathbf{F}\end{array}$ & $\begin{array}{l}7804 \\
8382\end{array}$ & $\begin{array}{l}14 \cdot 1 \\
15 \cdot 7\end{array}$ & $\begin{array}{c}1.00 \\
(9 \cdot 7) \\
1.00 \\
(6 \cdot 6)\end{array}$ & $\begin{array}{r}157 \\
83\end{array}$ & $\begin{array}{c}1 \cdot 27^{*} \\
(12 \cdot 1) \\
1 \cdot 51^{* *} \\
(9 \cdot 9)\end{array}$ & $\begin{array}{l}200 \\
178\end{array}$ & $\begin{array}{l}1 \cdot 53^{* * * *} \\
(14 \cdot 8) \\
2 \cdot 16^{* * * *} \\
(14 \cdot 5)\end{array}$ & $\begin{array}{l}272 \\
303\end{array}$ & $\begin{array}{l}1 \cdot 75^{* * *} \\
(17 \cdot 2) \\
2 \cdot 91^{* * *} \\
(20 \cdot 5)\end{array}$ & $\begin{array}{l}268 \\
331\end{array}$ & $\begin{array}{l}1.80^{*} \\
(17.9) \\
3.56^{* * *} \\
(26.1)\end{array}$ & $\begin{array}{l}204 \\
424\end{array}$ \\
\hline Lack of physical activity & $\begin{array}{l}\mathbf{M} \\
\mathbf{F}\end{array}$ & $\begin{array}{l}7809 \\
8366\end{array}$ & $\begin{array}{l}32.9 \\
40.8\end{array}$ & $\begin{array}{l}1.00 \\
(18.5) \\
1.00 \\
(21.2)\end{array}$ & $\begin{array}{l}299 \\
268\end{array}$ & $\begin{array}{l}1.41^{* * *} \\
(23.8) \\
1.32^{* *} \\
(26.9)\end{array}$ & $\begin{array}{l}396 \\
483\end{array}$ & $\begin{array}{l}2 \cdot 10^{* * * *} \\
(32 \cdot 7) \\
2 \cdot 44^{* * * *} \\
(41 \cdot 4)\end{array}$ & $\begin{array}{l}600 \\
862\end{array}$ & $\begin{array}{l}2 \cdot 89^{* * *} \\
(41 \cdot 6) \\
3 \cdot 24^{* * *} \\
(50 \cdot 9)\end{array}$ & $\begin{array}{l}650 \\
819\end{array}$ & $\begin{array}{l}5.00^{* * *} \\
(54.9) \\
4 \cdot 48^{* * *} \\
(60.9)\end{array}$ & $\begin{array}{l}624 \\
981\end{array}$ \\
\hline Type A behaviour & $\begin{array}{l}\mathbf{M} \\
\mathbf{F}\end{array}$ & $\begin{array}{l}7423 \\
7683\end{array}$ & $\begin{array}{l}15.9 \\
12 \cdot 8\end{array}$ & $\begin{array}{l}1.00 \\
(26.7) \\
1.00 \\
(18.0)\end{array}$ & $\begin{array}{l}423 \\
218\end{array}$ & $\begin{array}{l}0.59 * * * \\
(18 \cdot 1) \\
0.84 \\
(15 \cdot 3)\end{array}$ & $\begin{array}{l}291 \\
261\end{array}$ & $\begin{array}{l}0.41 * * * \\
(13 \cdot 0) \\
0.68 * * * \\
(12 \cdot 3)\end{array}$ & $\begin{array}{l}231 \\
238\end{array}$ & $\begin{array}{l}0 \cdot 32^{* * *} \\
(10 \cdot 4) \\
0 \cdot 58 * * * \\
(10 \cdot 0)\end{array}$ & $\begin{array}{l}150 \\
143\end{array}$ & $\begin{array}{c}0 \cdot 26^{* * *} \\
(8 \cdot 5) \\
0 \cdot 56^{* * *} \\
(9 \cdot 0)\end{array}$ & $\begin{array}{r}86 \\
126\end{array}$ \\
\hline
\end{tabular}

t Controlled for age and region

¥ Reference category

$\$$ Crude prevalence in \%

Number of subjects having risk factor

* $\mathrm{p}<0.05 ;{ }^{* *} \mathrm{p}<0.01 ; * * * \mathrm{p}<0.001$

small or non-existent. Regardless of sex, no significant variation in odds ratio for hypercholesterolaemia by stratum was noted. Significant differences in odds ratio occurred for hypertension and low HDLcholesterol only among females; however, when these measures were adjusted for relative body weight (body mass index), hypertension was no longer significantly related to social class and the latter had lost a good deal of its relevance regarding low HDL-cholesterol (odds ratio, middle class: $1.58, \mathrm{p}<0.05$; lower class: $1.58, \mathrm{p}<0.01)$.

Coronary prone behaviour (Type A) was clearly more prevalent with increasing socio-economic status. This was true for both sexes, although to a greater degree for men.

Because of the cumulative effect of multiple risk factors on CHD morbidity and mortality, the number of risk factors per person was ascertained. One can see from fig 1 that a distinct social class gradient existed,

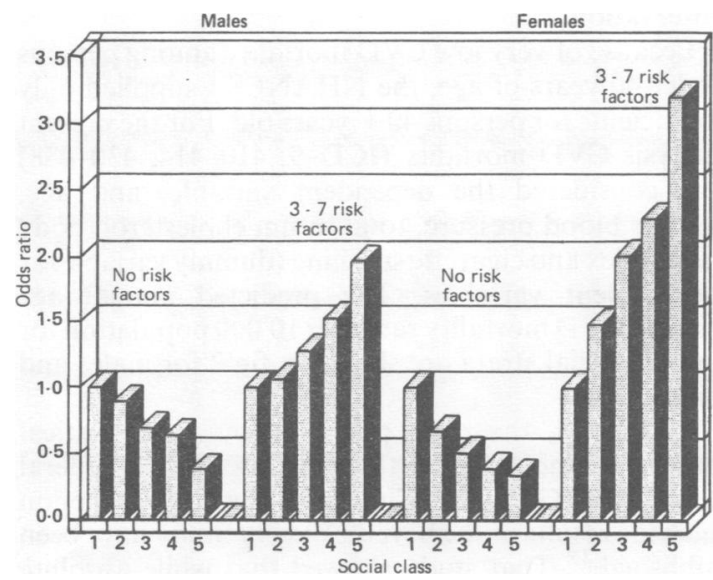

Fig 1 Odds ratios controlled for age and region for high and low risk factor load by social class 
even when adjusting for age and study region, both for the absence of any risk determinant and for the presence of three or more such factors. The lower the social class, the higher the odds ratio concerning prevalence of 3-7 factors and the lower that for a no risk factor profile.

Although the number of CHD risk factors present gives an idea about the probability of a person developing cardiovascular disease, more accurate estimations are arrived at using multiple logistic functions (MLF coefficients). The latter are derived from cohort studies having as end points CVD morbidity and mortality. Because of the lack of any adequate MLF coefficients for the FRG, we have used logistic regression coefficients developed from the United States NHANES I Epidemiologic Followup Survey (NHEFS). ${ }^{17}$ In comparison with other studies presenting logistic regression coefficients, those derived from NHEFS seem to be more appropriate for two reasons. First the study is more recent and with a longer follow up (on the average 9.5 years); and second, the study provides coefficients for both sexes and for specific age groups of interest to the GCP.

Data from the 1982-84 NHEFS were used to estimate sex specific multiple logistic models relating cardiovascular risk factors to mortality from ischaemic heart disease (IHD) and stroke for white persons 40-69 years of age at baseline. Persons 25-39 years of age at baseline were omitted from the analysis due to the small number of deaths in these groups. The NHEFS study population consisted of 2746 white males and 3369 white females who experienced (males) 235 and (females) 119 deaths from IHD and stroke. The dependent variable was the number of deaths where the underlying cause as reported on the death certificate is IHD (ICD-9 410-414) or stroke (ICD-9 $430-438$ ) divided by the number of person months of observation.

Because of very low CVD mortality among persons under 40 years of age, the NHANES I supplied only coefficients for persons $40+$ years old. For the present analysis CVD mortality (ICD-9: 410-414, 430-438) was considered the dependent variable, and age, systolic blood pressure, total serum cholesterol, body mass index and cigarette smoking (dummy variable) as independent variables. The predicted annual age specific CVD mortality rates per 10000 population for the five social strata are shown in fig 2 for males and females.

In general, the rates predicted by the statistical models are much higher than the rates in the Federal Republic of Germany. This is a known phenomenon since the results of the Seven Country Study have been published. ${ }^{18}$ That study showed that while absolute risk could not be predicted adequately when applying the US based MLF coefficients to a population in

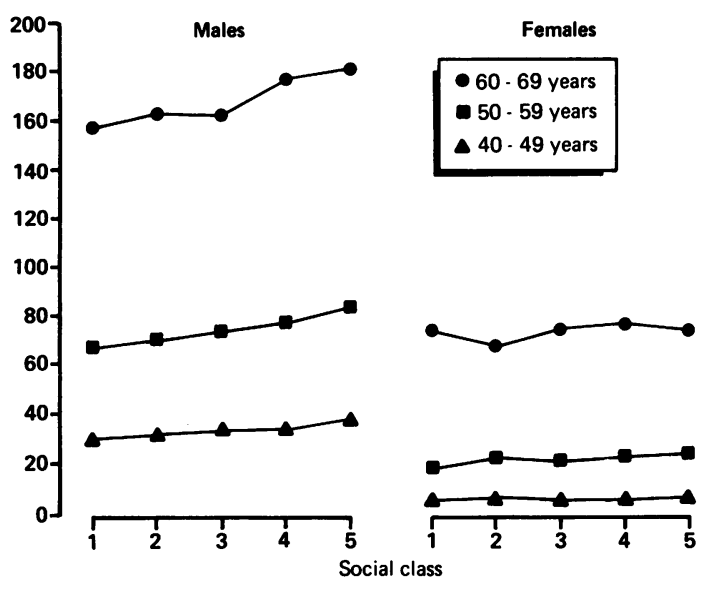

Fig 2 Predicted cardiovascular mortality multiple logistic functions-regression coefficients of NHEFS (variables: age, systolic BP, total serum cholesterol, BMI, smoking status) per 10000 population by social class, age and sex

western Europe, one was able to have rather accurate estimations of the relative effect of specific risk factors. The latter are more applicable to the research at hand $\mathbb{\Phi}$. and thus any bias produced by using MLF coefficients $\stackrel{\rho}{\mathbb{D}}$ 을 derived from the US study is assumed to be minimal.

The large differences between males and females regarding CVD mortality are also observed for actual CVD mortality rates in the Federal Republic of Germany. In five of the six age groups underco consideration, a clear increase in predicted CVD? mortality from the highest to the lowest social class was demonstrated. For men, the predicted CVD mortality in the lowest (relative to highest) social class is $24 \%$ higher among those $40-49$ years of age, $25 \%$ higher in the age group 50-59 years and $15 \%$ higher in the oldest age group. Women showed differences by social status in predicted CVD mortality only for those persons younger than 60 years $(28 \%$ higher, relative to highest class, for social class V, 40-49 years; $32 \%$ higher for social class $\mathrm{V}, 50-59$ years).

\section{Discussion}

Most population based health surveys present age and sex specific distributions of CHD risk factor prevalence. Regional differences are also often reported. What is most often lacking are studies examining risk factor prevalence in relation to social class even though for some factors there appears to be more variation according to such status than by age and sex.

Cigarette smoking, overweight and lack of physical activity were all found to be related to social class. Similar results have been noted recently for the 
MONICA-Augsburg Project in the Federal Republic of Germany, ${ }^{19}$ the British Regional Heart Study ${ }^{10}$ and the community based Swiss intervention study. ${ }^{20}$

No significant relation to social class existed regarding hypercholesterolaemia. Hypertension prevalence was found to be higher in the lower social classes only in females. The above mentioned German and Swiss studies also failed to show any significant correlation between social class and hypercholesterolaemia. The British study, however, pointed to higher cholesterol values for the upper relative to other social classes. Hypertension was not related to social class in Augsburg and in Switzerland. In Great Britain, the prevalence of this condition increased with decreasing social class.

The odds ratios for the risk factor "low HDLcholesterol" were significantly higher for women of the lower classes than those of the upper class. Males, however, had a nearly identical odds ratio distribution over the social strata. Type A behaviour was much more prevalent in the higher social classes. Similar results as the latter have been reported in a variety of other studies. ${ }^{21-23}$

Only crude rates for both the pooled surveys in the intervention regions and the reference area are presented. Thus the rates reported do not reflect the prevalence in the FRG as a whole, the latter requiring appropriate weighting for sampling fractions and non-response rates. Since we controlled for age and region, however, it is assumed that our findings carry over to the general population of the Federal Republic of Germany. This is supported by the fact that the log likelihood did not increase significantly when interaction terms between social class and region or age and region were included in the model.

The predicted CVD mortality was, for males in general and for females of the ages 40-59 years, clearly higher in the lower classes. The difference between the upper class and lowest class was far greater than $8 \%$, the amount of reduction in CVD mortality the GCP study is trying to achieve. Therefore, social class must be taken in consideration as an important contributing factor for the evaluation of the study.

One may suppose that the actual differences in CVD mortality between the social classes are even greater than those predicted based only on the risk factor prevalence. In a recent study in Great Britain, it was shown, among males, that a difference in such mortality between the manual and non-manual working classes ( $24 \%$ more CHD events in the former) remained after adjusting for smoking, blood pressure, cholesterol and age. ${ }^{9}$

The German Cardiovascular Prevention Study is funded by the Federal Ministry of Research and Technology and the Federal Ministry of Youth,
Family, Women Affairs and Health. The principal investigators are: E Greiser (Bremen Institute for Prevention Research and Social Medicine), J Hoeltz (Infratest Health Research, Munich), H Hoffmeister (Federal Health Office, Berlin), K-D Huellemann (Clinical Institute for Physiology and Sports Medicine, Prien), H Kreuter (Scientific Institute of German Physicians, Bonn), U Laaser (German Institute for Fighting High Blood Pressure, Heidelberg), E Nuessel (University Clinic of Heidelberg), J v Troschke (University of Freiburg).

Address for correspondence and reprints: $\mathrm{Dr} U$ Helmert, Department of Epidemiology, Bremen Institute for Prevention Research and Social Medicine, St-Juergen-Strasse 1, D-2800 Bremen, FRG.

\section{References}

${ }^{1}$ World Health Organization. Prevention of coronary heart disease. Report of a WHO Expert Committee. Technical Report Series 678. Geneva: WHO, 1978.

${ }^{2}$ Kaplan NM, Stamler J, eds. Prevention of coronary heart disease. Practical management of the risk factors. Philadelphia: WB Saunders, 1983.

${ }^{3}$ Syme SL, Berkman LF. Social class, susceptibility and sickness. Am J Epidemiol 1976; 104: 1-8.

${ }^{4}$ Wilkinson RG, ed. Class and health. Research and longitudinal data. London, New York: Tavistock Publications, 1986.

${ }^{5}$ Black D, Morris JN, Smith C, Townsend P. Inequalities in health. The Black Report. Harmondsworth: Penguin Books, 1980.

${ }^{6}$ Marmot MG, Morris JN. The social environment. In: Holland WW, Datels R, Knox G, eds. Oxford textbook of public health, Volume 1. Oxford, New York, Toronto: Oxford University Press, 1984: 97-118.

${ }^{7}$ Susser M. Epidemiology, health and society. New York: Oxford University Press, 1987.

${ }^{8}$ Fox AJ, Goldblatt PO, Jones DR. Social class mortality differentials: artefact, selection or life circumstance? $J$ Epidemiol Community Health 1985; 39: 1-8.

${ }^{9}$ Marmot MG, McDowell ME. Mortality decline and widening social inequalities. Lancet 1986; ii: $274-6$.

${ }^{10}$ Pocock SJ, Shaper AG, Cook DG, Phillips AN, Walker M. Social class differences in ischaemic heart disease in British men. Lancet 1986; ii: 197-201.

11 GCP Study Group. The German Cardiovascular Prevention Study (GCP). Eur Heart J 1988; 9: 1058-66.

12 Helmert U, Greiser E. Soziale Schicht und Risikofaktoren für koronare Herzkrankheiten. Resultate der regionalen DHP-Gesundheitssurveys. Soz Praeventivmed 1988; 33: 233-40.

${ }^{13}$ Bortner RW. A short rating scale as a potential measure of pattern A behaviour. J Chron Dis 1969; 22: 87-91.

${ }^{14}$ Kleinbaum DG, Kupper U, Morgenstern H. Epidemiological research. Principles and quantitative methods. Belmont: Lifetime Learning Publications, 1981.

15 Greenberg RS, Kleinbaum DG. Mathematical modelling strategies for the analysis of epidemiologic research. Ann Rev Public Health 1985; 6: 223-45. 
${ }^{16}$ Harrel FE. The LOGIST-Procedure. In: SUGI supplement library user's guide, 1983 Edition. Cary: SAS Institute, 1983: 181-202.

${ }^{17}$ National Center for Health Statistics. Plan and operation for the NHANES I Epidemiologic Followup Study 19821984. Vital and Health Statistics, series I, No. 22. DHHS Publication No (PHS) 87-1324. Public Health Service. Washington: US Government Printing Office, June 1987.

${ }^{18}$ Keys A. Seven Countries-A multivariate analysis of death and coronary heart disease. Cambridge, London: Harvard University Press, 1980.

${ }^{19}$ Haertel U, Keil U. Psychosoziale Faktoren und HerzKreislauf-Krankheiten. Laufende Studien und erste Ergebnisse im MONICA-Projekt Augsburg der WHO. Fortschr Med 1986; 104: 943-7.
${ }^{20}$ Schweizerisches Nationales Forschungsprogramm 1A. Die Epidemiologie der Risikofaktoren für kardiovaskuläre Krankheiten in der Schweiz. Schweiz Med Wochenschr (Suppl) 1981; 12: 5-62.

${ }^{21}$ Mettlin C. Occupational careers and the prevention of coronary prone behaviour. Social Sci Med 1976; 10: $367-72$.

22 Shekelle RB, Schoenberger JA, Stamler J. Correlates of the JAS type A behaviour pattern score. J Chron Dis 1976; 29: $381-94$.

${ }^{23}$ Waldron I. The coronary-prone behaviour pattern, blood pressure, employment and socioeconomic status in women. J Psychosom Res 1978; 22: 79-87.

Accepted for publication October 1988 